\title{
Graphene: A new technology for agriculture
}

\author{
Grafeno: Uma nova tecnologia para a agricultura \\ Grafeno: Una nueva tecnología para la agricultura
}

Received: 02/10/2021 | Reviewed: 02/20/2021 | Accept: 02/22/2021 | Published: 02/28/2021

André May
ORCID: https://orcid.org/0000-0001-6157-7215
Empresa Brasileira de Pesquisa Agropecuária Meio Ambiente, Brasil
E-mail: andre.may @embrapa.br
Luciana Fontes Coelho
ORCID: https://orcid.org/0000-0001-5474-3465
E-mail: lufonco@ @yahoo.com.br
Empresa Brasileira de Pesquisa Agropecuária Meio Ambiente, Brasil
Evandro Henrique Figueiredo Moura da Silva
ORCID: https://orcid.org/0000-0002-0913-8140
Universidade de São Paulo, Brasil
E-mail: ehfmsilva@ usp.br
Ronaldo da Silva Viana
Faculdades de Ciências Agrárias e Tecnológicas, Brasil
E-mail: ronaldo@dracena.unesp.br
Nilson Aparecido Vieira Junior
ORCID: https:/orid.org/o000-0001-6819-5092
ORCID: https://orcid.org/0000-0002-5651-5893
Universidade de São Paulo, Brasil
E-mail: nilsonvieirajunior@ usp.br
Williams Pinto Marques Ferreira
ORCID: https://orcid.org/0000-0002-0115-9334
E-mail: williams.ferreira@embrapa.br

\begin{abstract}
This article presents a review on the use of graphene in various segments, elucidating that this product can be used in various industrial sectors. These include mainly agriculture (as in large crops of high relevance, such as coffee), the food industry and the environment, as a plant growth stimulator and in fertilizers, nanoencapsulation and smart-release systems, antifungal and antibacterial agents, smart packaging, water treatment and ultrafiltration, contaminant removal, pesticide and insecticide quantitation, detection systems and precision agriculture. However, some challenges can be overcome before the graphene-based nanoparticle is used on a large scale. In this way, before using the product in the environment, it is necessary to determine whether the technology is safe for the soil-plant system and consumers. Furthermore, the cost of its use can also be a limiting factor depending on the level applied. Therefore, this review proposes to examine the diverse literature to explain the effects of the use of graphene in agriculture, plants and soil microorganisms. Accordingly, this article discusses and presents the possibilities of application of graphene in agriculture, plants and soil microorganisms.
\end{abstract}

Keywords: Graphene; Graphene oxide; Agriculture; Nanomaterials; Carbon.

\section{Resumo}

Este artigo apresenta uma revisão sobre o uso do grafeno em vários segmentos, elucidando que esse produto pode ser usado em vários setores da indústria, principalmente na agricultura, como em grandes culturas agrícolas de alta relevância como café, por exemplo, na indústria alimentícia e no meio ambiente, como estimulador de crescimento de plantas e fertilizantes, nanoencapsulação e sistemas de liberação inteligente, agentes antifúngicos e antibacterianos, embalagens inteligentes, tratamento de água e ultrafiltração, remoção de contaminantes, quantificação de pesticidas e inseticidas, sistemas de detecção e agricultura de precisão. Contudo, alguns desafios podem ser superados antes que a nanopartícula à base de grafeno seja utilizada em escala. Assim, antes do uso do produto no ambiente é necessário verificar se a tecnologia é segura para o sistema solo-planta e para os consumidores, além disso, o custo de utilização também pode ser um limitador, conforme a dose utilizada. Portanto, o objetivo desta revisão é analisar as diversas literaturas, explicando os efeitos do uso de grafeno na agricultura, plantas e microrganismos no solo. Assim, com o presente artigo, busca-se discutir e apresentar as possibilidades aplicativas do uso do grafeno na agricultura, nas plantas e nos microrganismos no solo.

Palavras-chave: Grafeno; Óxido de grafeno; Agricultura; Nanomateriais; Carbono. 


\section{Resumen}

El grafeno se puede utilizar en diversos sectores de la industria, principalmente en la agricultura, en la industria alimentaria y en el medio ambiente, como estimulador del crecimiento de plantas y fertilizantes, nanoencapsulación y sistemas de liberación inteligente, agentes antifúngicos y antibacterianos, envases inteligentes, tratamiento de agua y ultrafiltración, remoción de contaminantes, cuantificación de pesticidas e insecticidas, sistemas de detección y agricultura de precisión. Sin embargo,algunos desafíos necesitan ser superados antes de que la nanopartícula basada en grafeno se utilice a escala. Así, antes de usar el producto en el medio ambiente, es necesario verificar si la tecnología es segura para el sistema suelo-planta y para los consumidores, además, el costo de uso también puede ser un limitante, dependiendo de la dosis utilizada. Así, el objetivo de esta revisión es analizar la diversa literatura, explicando los efectos del uso de grafeno en agricultura, plantas y microorganismos en el suelo.

Palabras clave: Grafeno; Óxido de grafeno; Agricultura; Nanomateriales; Carbono.

\section{Introduction}

In 1948, the creation of electron microscopy allowed the visualization of the first images of few-layer graphite. Thereafter, the search for the "isolation of graphene" began. Later on, in 2010, researchers Andre Geim and Constantine Novoselov, from the University of Manchester, won the Nobel Prize in physics for discovering graphene and its properties, extracting the famous graphene layers from graphite.

Graphene can be used in agriculture and various sectors of the high-tech and food industries. This material can be used in different ways in these segments, e.g. (I) as a plant growth stimulator and a component of fertilizers (Zaytseva \& Neumann, 2016); (II) in nanoencapsulation and smart-release systems (Andelkovic et al., 2018; Kabiri et al., 2017); (III) as an antifungal and antibacterial agent (Wang et al., 2014); (IV) in smart packaging (Sundramoorthy et al., 2018); (V) in water treatment and ultrafiltration (Homaeigohar \& Elbahri, 2017); (VI) in contaminant removal (Wu et al., 2012); (VII) for pesticide and insecticide quantitation (Hou et al., 2013); and (VIII) in detection systems and precision agriculture (Wu et al., 2014).

Graphene may be considered a renewable material, as it does not depend on natural reserves to be produced (Zaytseva $\&$ Neumann, 2016). Despite being a promising material, its interactions with the environment are not well defined (Zaytseva \& Neumann, 2016).

\section{Methodology}

This review proposes to present current literature findings on various applications of graphene in agriculture, the environment and the food industry as well as the consequences of its application on the environment, plants and soil microorganisms. In addition, this study examines the prospects and the real needs for more promising and assertive research assessing the impact of this new technology.

In this way, before using the product in the environment, it is necessary to determine whether the technology is safe for the soil-plant system and consumers. Furthermore, the cost of its use can also be a limiting factor depending on the level applied. Therefore, this review proposes to examine the diverse literature to explain the effects of the use of graphene in agriculture, plants and soil microorganisms. Accordingly, this article discusses and presents the possibilities of application of graphene in agriculture, plants and soil microorganisms.

\section{Characteristics, Synthesis and Properties}

Graphene is known to be formed by layers of carbon atoms attached in hexagonal structures (Soldano et al., 2010). Some noteworthy physical properties of graphene include its extremely high optical transparency, of up to 97.7\% (Brownson et al., 2012); high thermal conductivity, of $5000 \mathrm{~W} \mathrm{~m}^{-1} \mathrm{~K}^{-1}$ (Balandin et al., 2008); and broad specific surface area, of $2630 \mathrm{~m}^{2} \mathrm{~g}^{-1}$ (Zhu et al., 2010). The size of graphene interferes with its charge distribution, thermal conductivity, UV absorbance spectra and capacitance (Choi et al., 2011; Ćirić et al., 2010; Luo et al., 2010; Nika et al., 2012; Zhou et al., 2011). 
Depending on reaction conditions, graphene nanomaterials (GNMs) can be formed with different chemical surfaces, which differ in morphology and oxygen content (O:C ratio). For this reason, their electrochemical and conductivity responses differ. Because it has higher amounts of sp2-hybridized carbon, the reduced form of graphene oxide (rGO) has a higher conductivity than graphene oxide (GO) (Jain \& Mishra, 2016).

Compared to primitive graphene, GO, with various oxygen groups, has relatively high solubility. The biocompatibility of GO can be improved with the use of polyetherimide (PEI) and polyethylene glycol (PEG) (Seo et al., 2011). The nanotoxicity of graphene can also be reduced with the use of amines, for instance (Lee et al., 2011).

Negative (anionic) surfaces are less toxic than positive (cationic) surfaces, whereas neutral ones are more biocompatible (Goodman et al., 2004). This is due to the affinity of cationic particles for phospholipids or negative proteins. However, the effect of the surface charges of graphene on nanotoxicology is not yet fully elucidated.

Graphene gained prominence in the 2000s, when Geim and Novolosev isolated and characterized it (Brownson et al., 2012) for the first time, in a technique known as the 'Scotch tape method' (Novoselov et al., 2005). The method, which consisted of removing pieces of graphite with Scotch tape, granted Geim and Novoselov the physics prize in 2010. By this technique, the pieces of graphite are exfoliated with more adhesive tape and applied to silica sheets until an atom-thick layer of graphite-graphene-is finally immobilized in the application (Novoselov et al., 2005).

Nonetheless, large-scale graphene production requires the use of other methods. At present, producers employ the "Hummers" method and its variations developed by William Hummers in the late 1950s (Hummers \& Offeman, 1958). This method uses strong acids and powerful oxidizing agents to separate the graphene layers from the graphite source. Although other production methods exist, they are little used.

There is also the possibility of producing graphene from crop residues, which could further reduce production costs, e.g., agricultural waste from sugarcane bagasse (Somanathan et al., 2015). In addition, graphene can be produced from bacteria such as Shewanella (Lehner et al., 2019), with high efficiency in terms of cost, time savings and the environment in comparison to chemical methods of graphene production.

\section{Graphene Applications in Agriculture, the Food Industry and the Environment}

Graphene can be used in agriculture and various sectors of the high-tech and food industry, e.g. (I) as a plant growth stimulator and a component of fertilizers (Zaytseva \& Neumann, 2016); (II) in nanoencapsulation and smart-release systems (Andelkovic et al., 2018; Kabiri et al., 2017); (III) as an antifungal and antibacterial agent (Wang et al., 2014); (IV) in smart packaging (Sundramoorthy et al., 2018); (V) in water treatment and ultrafiltration (Homaeigohar \& Elbahri, 2017); (VI) in contaminant removal (Wu et al., 2012); (VII) for pesticide and insecticide quantitation (Hou et al., 2013); and (VIII) in detection systems and precision agriculture (Wu et al., 2014).

\section{a. Nanoencapsulation and smart-release systems}

Although fertilizers are essential in modern agriculture, their use efficiency is still in need of enhancement, given the losses to the environment. In this respect, the use of graphene in the development of new slow-release fertilizers can be an important alternative to reduce these losses (Andelkovic et al., 2018; Kabiri et al., 2017). An example is the coffee crop, which currently uses large amounts of slow-release fertilizers on a large scale.

Graphene oxide is composed of a negatively charged layer capable of retaining cationic micronutrients such as zinc $(\mathrm{Zn})$ and copper $(\mathrm{Cu})$, or anions such as negatively charged phosphate. For this purpose, GO must be treated with iron (Fe). Thus, the release of these nutrients is slower than soluble fertilizers and can better respond to the demands of cultivated plants (Kabiri et al., 2017). 
It is known that, in covering fertilizer granules, a graphene layer can enhance their physical resistance, preventing friction damage and degradation during manufacture, transport and application (Kabiri et al., 2017). Moreover, the addition of $\mathrm{GO}$ in the encapsulation process of slow-release fertilizers may be an alternative for this segment, preventing waste and overdose (Zhang et al., 2014). In this context, GO can be used in crops with high added value, e.g. vegetables, fruits or coffee.

The slower release of $\mathrm{P}$ is achieved by applying the GO-Fe-P composite, thereby reducing the possibility of soluble $\mathrm{P}$ leaching, in comparison to the commercial fertilizer monoammonium phosphate (MAP) (Andelkovic et al., 2018).

For potassium nitrate, the nutrient release process was extended for $8 \mathrm{~h}$ in water after the fertilizer was encapsulated with GO films (Zhang et al., 2014).

\section{b. Plant growth stimulators and fertilizers}

The use of graphene can increase germination rates and stimulate growth, but it can also have contradictory effects depending on various factors such as time of exposure, concentration, particle size, plant species, among others. Therefore, further research is warranted to determine the appropriate concentration to improve plant growth without causing phytotoxicity and negative environmental changes (Zaytseva \& Neumann, 2016).

\section{c. Antifungal and antibacterial agents}

Graphene has antifungal activity, which renders it an excellent product for the development of new fungicides (Wang et al., 2014). Reduced graphene oxide has the potential to inhibit the mycelial growth of three fungi-Aspergillus oryzae, Fusarium oxysporum and Aspergillus niger (Sawangphruk et al., 2012) - through damage caused to the induced microbial membrane (Chen et al., 2014), changes in electron transport (Shaobin Liu et al., 2012) and oxidative stress due to the antimicrobial activity of GO (Hui et al., 2014; Mangadlao et al., 2015). Larger graphene sheets are known to have greater antibacterial activity than small sheets (Akhavan \& Ghaderi, 2010).

In addition, graphene has strong cytotoxicity on bacteria (Liu et al., 2011). Escherichia coli (Akhavan \& Ghaderi, 2010) and Pseudomonas aeruginosa (Gurunathan et al., 2012) are known to have their growth inhibited by GO and rGO nanoparticles, with the unreduced GO being less toxic than its hydrazine-reduced counterpart (Akhavan \& Ghaderi, 2010).

The inactivation of $R$. solanacearum is caused by a rupture of the cell membrane by the antibacterial activity of graphene in its different preparation forms, which results in the release of the cytoplasmic content of the bacterial cell (Wang et al., 2012)

Antibacterial activity may be dependent on the size of the GO sheet. Large GO sheets were found to have less effective antibacterial action than small GO leaves (Perreault et al., 2015).

The quality of cut roses can be improved and their pot life extended with the use of GO, due to its antimicrobial activity. Longer pot life, better water relationships and larger diameter were observed in cut roses when the plant was grown at a low rate of $\mathrm{GO}(0.1 \mathrm{mg} / \mathrm{L})$, as a result of its germicidal and preservative action (He et al., 2018).

\subsection{Graphene-Silver (Ag) composite}

Until the 1940s, silver was widely used to treat bacterial infections, but following the discovery of the first, most effective antibiotics, it lost ground. However, due to the development of antibiotic resistance by some microorganisms, silver is regaining scientific relevance (Möhler et al., 2018).

Expansive use of silver is limited by its cytotoxicity and low stability (Cai et al., 2012). For these reasons, hybrid elements must be used, such as graphene and silver nanoparticles (AgNPs), which possess strong antibacterial properties against many gram-negative and gram-positive strains (Shao et al., 2015). Nonetheless, the factors that affect its antibacterial activities and antibacterial mechanism remain unclear (Tang et al., 2013). Among the AgNPs, antibacterial GO-AgNPs improve activity 
against the gram-positive bacterial strain B. subtilis and the gram-negative bacterial strain E. coli (Ma et al., 2013).

The permeability of sugars and proteins from the cell wall of Bacillus subtilis and S. aureus during the interaction with these GO-AgNPs resulted in 100\% effectiveness in the elimination of bacterial colonies (Das et al., 2013).

To prevent the development of microorganisms on medical devices and food packaging, a GO-Ag nanocomposite prepared in the presence of sodium citrate and silver nitrate can be used. With this property, the nanocomponent may be able to prevent P. aeruginosa from developing on stainless-steel surfaces (Faria et al., 2014; Tang et al., 2013).

At a concentration of $100 \mu \mathrm{g} / \mathrm{mL}$, the rGO-nAg nanocomposite was more effective against Escherichia coli, Proteus mirabilis and Staphylococcus aureus than $\mathrm{rGO}$ or $\mathrm{nAg}$. The nanocomposite was as active as the systemic antibiotic nitrofurantoin against E. coli, S. aureus and P. mirabilis (Prasad et al., 2017). Moreover, nitrofurantoin was slower in inhibition than the rGOnAg nanocomposite.

Graphene oxide-AgNPs nanocomposites provided an almost three and seven times greater inhibition of Fusarium than pure suspensions of AgNPs and GO, respectively. Thus, the plant infection by F. graminearum can be controlled by GO-AgNPs nanocomposites (Chen et al., 2016).

Several biocides have been used to control Xanthomonas oryzae in rice. However, indiscriminate use of these products is known to ultimately promote resistance of the microbial community, in addition to residual contamination of rice, causing risks to human health. Liang et al. (2017) observed that a low concentration of GO-Ag $(2.5 \mu \mathrm{g} / \mathrm{mL})$ completely inactivated some bacterial species.

The severity of bacterial spot, one of the most important diseases of tomato, caused by Xanthomonas sp., can be significantly reduced with the application of GO-Ag at $100 \mathrm{ppm}$, as compared with lack of treatment, without risks of phytotoxicity (Ocsoy et al., 2013).

\subsection{Graphene-Germanium (Ge) composite}

Germanium (Ge) is spread over the Earth's crust. As an element analogous to silicon ( $\mathrm{Si}$ ), Ge shows chemical properties and characteristics very similar to this element (Wiche et al., 2018).

As an elementary semiconductor material, germanium $(\mathrm{Ge})$ has been an attractive candidate for the manufacture of microelectronic devices. The presence of graphene gives Ge a satisfactory antibacterial capacity against Staphylococcus aureus and an acceptable antibacterial capacity against Escherichia coli, due to its action of phospholipid disturbance and electron extraction at the interface between graphene and the biomembrane of the microorganism (Geng et al., 2016).

Graphene films on $\mathrm{Ge}$ and copper $(\mathrm{Cu})$ inhibited the growth of $S$. aureus and E. coli (Li et al., 2014).

\section{a. Contaminant removal}

Environmental contaminants can be removed with graphene-based materials. Wu et al. (2012) used graphene as a new fiber-coating material for solid phase microextraction (SPME) coupled with HPLC-DAD for the detection of four triazine herbicides (atrazine, ametrine and prometrine) in water samples. The recovery of triazine herbicides in water samples ranged between 86.0 and $94.6 \%$. The highest extraction efficiency was obtained with graphene-coated fiber, as compared with commercial fibers (CW/TPR, $50 \mathrm{~mm}$; PDMS/DVB, $60 \mathrm{~mm}$ ).

In the future, graphene oxide may also act in the removal of dyes (do Nascimento et al., 2020). Results obtained with the sample with less $\mathrm{H}_{2} \mathrm{SO}_{4}$ (GO-21) showed better performance in the removal of methylene (99\% removal) and light blue (29\% removal). The kinetics showed that balance was reached in $30 \mathrm{~min}$, removing $67.43 \%$ of the current and $90.23 \%$ of the effluent turbidity. Phytotoxicity tests indicated that wastewater treated with GO-21 was less toxic than other analyzed samples of wastewater (Nascimento et al., 2020). You et al. (2018) demonstrated that applied graphene oxide membranes can remove 
organic matter from water.

The maximum degradation rates of xylene (BTEXs), ethylbenzene, toluene and benzene in cultures incubated for 10 weeks with biochar $(20 \mathrm{mg} / \mathrm{L})$ and graphene oxide $(0.02 \mathrm{mg} / \mathrm{L})$ were $77.6 \%$ and $76.5 \%$, respectively. The maximum degradation rates of $n$-alkane in cultures incubated for 10 weeks with biochar $(100 \mathrm{mg} / \mathrm{L})$ and graphene oxide $(2 \mathrm{mg} / \mathrm{L}) \mathrm{were} 77.8 \%$ and $70.0 \%$, respectively (Song et al., 2019).

\subsection{Smart food packaging}

Incorporating a layer of graphene into the packaging can provide a substantial reduction in its permeability, prolonging the useful life of a given food product and contributing to the maintenance of its quality and safety (Sundramoorthy et al., 2018).

\subsection{Water treatment and ultrafiltration}

The exponential growth of environmental pollution caused by the increasing global industrialization and the demographic explosion resulted in the contamination of water resources. In this respect, graphene can be of great use thanks to its large contact surface and high mechanical resistance, atomic thickness, microporosity and reactivity to non-polar and polar pollutants in water. These characteristics provide excellent water purification efficiency, high permeability and water selectivity (Homaeigohar \& Elbahri, 2017). Specific studies have shown that a single layer of porous graphene can be used as a desalination membrane (Homaeigohar \& Elbahri, 2017; Surwade et al., 2015).

\section{a. Impact of Graphene on Plants}

Graphene is currently well known for its characteristics and abilities in the regulation of plant growth (Cheng et al., 2016; Shen et al., 2019).

Depending on the level used, graphene oxides can reduce chlorophyll, inhibit plant growth, damage cell structures and induce genotoxicity or oxidative stress in plants (Anjum et al., 2014; Nair et al., 2012; Zhao et al., 2014).

Root exudates can be stimulated by the use of primitive graphene oxide as secondary metabolites, small-molecule acids, alkanes, alcoholates and amino acids (Du et al., 2015).

At a low concentration (5 mg L ${ }^{-1}$ ) (Begum et al., 2011), graphene can influence plant growth (Hu et al., 2014; Liu et al., 2015). In contrast, higher levels ( $\left.\geq 50 \mathrm{mg} \mathrm{L}^{-1}\right)$ can inhibit development (Anjum et al., 2013, 2014).

After 20 days of exposure to graphene (500 to $2000 \mathrm{mg} / \mathrm{L}$ ), cabbage, spinach and tomato plants showed reduced growth and biomass, when compared with their control counterparts (Begum et al., 2011). Depending on the graphene concentration, the number and size of leaves on the plant may decrease and necrotic lesions appear due to oxidative stress. However, little or no significant toxic effect was observed on lettuce. Thus, the level, the time of exposure and the plant species have a great influence on the enhancement of the effect of graphene (Begum et al., 2011).

With the use of 1 to $10 \mathrm{mg} / \mathrm{L}$ of GO, the length of the adventitious root and the number of lateral roots in 'Gala' apple (Malus domestica), at three weeks of age, were inhibited. However, between the GO rates of 0.1 and $1 \mathrm{mg} / \mathrm{L}$, rooting rates and the number of adventitious roots showed a significant increase when compared with the control (without GO). The treatment with GO increased the activity of the catalase (CAT), superoxide dismutase (SOD) and peroxidase (POD) enzymes in apple trees, as compared with the controls (Li et al., 2018).

Low graphene concentrations accelerated the germination of tomato seeds, in comparison to the control treatment (Zhang et al., 2015). This response is explained by the fact that graphene penetrates the seed epidermis, making it break more easily, thereby capturing more water and resulting in faster and more efficient germination. As regards seedling growth, graphene was also able to penetrate the cells at the tip of the root, promoting longer roots, but resulting in less shoot biomass (Zhang et 
al., 2015).

Radish growth increased with the Ag-GO rates of 0.2 to $1.6 \mathrm{mg} / \mathrm{mL}$, but the level of $0.8 \mathrm{mg} \mathrm{mL}^{-1}$ slowed the growth of cucumber, and rates above $0.2 \mathrm{mg} / \mathrm{mL}$ inhibited the growth of alfalfa (Kim et al., 2020).

At limited concentrations, GO increases growth, root length, leaf area, number of leaves and the formation of buds and flowers in Arabidopsis thaliana and watermelon. In addition, GO can also affect the ripening, circumference and sugar content of watermelon (Park et al., 2020).

The treatment of Brassica napus with 25 to $100 \mathrm{mg} / \mathrm{L}$ of GO resulted in a shorter root length, as compared with control. Treatment with GO also resulted in a lower indole acetic acid content and a higher abscisic acid content, in comparison to control samples (Cheng et al., 2016).

Seeds of coriander and garlic plants treated with $0.2 \mathrm{mg} / \mathrm{mL}$ of graphene for $3 \mathrm{~h}$ before planting exhibited an increase in growth rate (Chakravarty et al., 2015).

Corn plants exposed to a low concentration of sulfonated graphene $\left(50 \mathrm{mg} \mathrm{L}^{-1}\right)$ showed an increase in plant height (Liu et al., 2015), whereas the opposite effect was described at a high concentration (500 $\mathrm{mg} \mathrm{L}^{-1}$ ) (Ren et al., 2016).

In this way, adverse effects depend on the applied level, and phytotoxicity mechanisms involve oxidative stress-induced necrosis (Begum et al., 2011). Graphene oxide can impair the oxidative balance of plants, inhibiting photosynthesis and plant growth (Du et al., 2016).

Many questions still require investigation, such as the capture and translocation of graphene in plants, their gene expression and electrochemical interactions between the soil and the rhizosphere (Hu \& Zhou, 2013).

\section{b. Effects of Graphene on Microbial Diversity}

According to Ren et al. (2015), the rate of removal of pollutants from the soil can be increased by using a small amount of graphene ( $<100 \mathrm{mg} / \mathrm{kg}$ of soil), increasing the soil microbial enzymatic activity and bacterial biomass in a short time. When the graphene concentration in the soil was extremely high, the number of bacteria present in the soil decreased significantly. This may have adverse influences on the soil nitrogen cycle, due to the difficulty of growth of iron-reducing bacteria and nitrogen-fixing bacteria.

In the natural environment, the dispersibility, stability and toxicity of GO composites were significantly lower than those of graphene in liquid medium (Mejías Carpio et al., 2012). Graphene oxide can attack microbial cells, destroying the cellular structure and leading to cell death (Mejías Carpio et al., 2012). Due to its high stability, GO is not easily degraded in the environment (Kurapati et al., 2015). Chen et al. (2017) found that the influence of graphene on soil microorganisms is greater than in the aquatic environment, due to its low solubility in water. In addition, the toxicity of graphene is significantly lower than that of GO.

Wang et al. (2013) observed a $10 \%$ increase in the activity of oxidizing bacteria with the use of $0.1 \mathrm{~g} / \mathrm{L}$ GO. The GO concentrations of 0.05 to $0.1 \mathrm{mg} / \mathrm{mL}$ induced an increase in the production of proteins and carbohydrates (Wang et al., 2013).

Graphene can also influence plant growth-promoting rhizobacteria. The effect of graphene was evaluated on five bacterial isolates selected from the rhizosphere of an agricultural field, identified as B. marisflavi, B. cereus, B. megaterium, B. subtilis and $B$. mycoides. Results suggest that $\mathrm{GO}$ reduces cell viability depending on the concentration and time, demonstrating that it can negatively affect bacterial communities in the soil (Gurunathan, 2015).

Combarros et al. (2016) found that GO concentrations above $50 \mathrm{mg} \mathrm{L}^{-1}$ inhibited the growth of P. putida. Even at the low rate of $1 \mathrm{mg} \cdot \mathrm{kg}^{-1}$, rGO has the ability to interfere with bacterial composition (Forstner et al., 2019). 
On the other hand, the addition of graphene increased the richness and diversity index of the bacterial community in Cambisols, varying with the graphene concentration $\left(0,10,100\right.$ or $\left.1000 \mathrm{mg} \mathrm{kg}^{-1}\right)$ and incubation time (7, 15, 30, 60 or 90 days) (Song et al., 2018).

Finally, graphene in the environment can be influenced by salt, $\mathrm{pH}$, natural organic matter or temperature. Recently, Lu et al. (2017) investigated the effects of montmorillonite, illite and kaolinite on GO transport. Graphene oxide transport is significantly inhibited by the presence of clay minerals, and the effects of inhibition followed the kaolinite > montmorillonite $>$ illite order. The researchers suggested that the effects of transport inhibition are due to the existence of positively charged edge sites in these clay minerals. Sun et al. (2015) found that GO retention can be reduced with increasing sand particle size (coarse $<$ medium < fine).

\section{Conclusion}

Research on graphene evolved rapidly, bringing innovations to the industrial sector, agriculture and environment. Studies already exist on the response of plants to graphene. Depending on its concentration, there can be variations in the degree of absorption by plants, and phytotoxicity is possible. However, low levels of graphene can be beneficial for the development of some plants. Thus, some challenges still need to be overcome before the graphene-based nanoparticle is used in the field. Future research must still focus on efforts to define doses in different real agricultural systems.

\section{References}

Akhavan, O., \& Ghaderi, E. (2010). Toxicity of graphene and graphene oxide nanowalls against bacteria. ACS Nano, 4(10), 5731-5436. https://doi.org/10.1021/nn101390x

Andelkovic, I. B., Kabiri, S., Tavakkoli, E., Kirby, J. K., McLaughlin, M. J., \& Losic, D. (2018). Graphene oxide-Fe (III) composite containing phosphate - A novel slow release fertilizer for improved agriculture management. Journal of Cleaner Production, 185(Iii), 97-104. https://doi.org/10.1016/j.jclepro.2018.03.050

Anjum, N. A., Singh, N., Singh, M. K., Sayeed, I., Duarte, A. C., Pereira, E., \& Ahmad, I. (2014). Single-bilayer graphene oxide sheet impacts and underlying potential mechanism assessment in germinating faba bean (Vicia faba L.). Science of the Total Environment, 472, 834-841. https://doi.org/10.1016/j.scitotenv.2013.11.018

Anjum, N. A., Singh, N., Singh, M. K., Shah, Z. A., Duarte, A. C., Pereira, E., \& Ahmad, I. (2013). Single-bilayer graphene oxide sheet tolerance and glutathione redox system significance assessment in faba bean (Vicia faba L.). Journal of Nanoparticle Research, 15(7), 1-12. https://doi.org/10.1007/s11051-013-1770-7

Balandin, A. A., Ghosh, S., Bao, W., Calizo, I., Teweldebrhan, D., Miao, F., \& Lau, C. N. (2008). Superior thermal cond uctivity of single-layer graphene. Nano Letters, 8(3), 902-907. https://doi.org/10.1021/n10731872

Begum, P., Ikhtiari, R., \& Fugetsu, B. (2011). Graphene phytotoxicity in the seedling stage of cabbage, tomato, red spinach, and lettuce. Carbon, 49(12), 39073919. https://doi.org/10.1016/j.carbon.2011.05.029

Brownson, D. A. C., Kampouris, D. K., \& Banks, C. E. (2012). Graphene electrochemistry: Fundamental concepts through to prominent applications. In Chemical Society Review, 41(21), 6944-6976. https://doi.org/10.1039/c2cs35105f

Cai, X., Tan, S., Yu, A., Zhang, J., Liu, J., Mai, W., \& Jiang, Z. (2012). Sodium 1-naphthalenesulfonate-functionalized reduced graphene oxide stabilizes silver nanoparticles with lower cytotoxicity and long-term antibacterial activity. Chemistry - An Asian Journal, 7(7), 1664-1670. https://doi.org/10.1002/asia.201200045

Chakravarty, D., Erande, M. B., \& Late, D. J. (2015). Graphene quantum dots as enhanced plant growth regulators: Effects on coriander and garlic plants. Journal of the Science of Food and Agriculture, 95(13), 2772-2778. https://doi.org/10.1002/jsfa.7106

Chen, J., Peng, H., Wang, X., Shao, F., Yuan, Z., \& Han, H. (2014). Graphene oxide exhibits broad-spectrum antimicrobial activity against bacterial phytopathogens and fungal conidia by intertwining and membrane perturbation. Nanoscale, 6(3), 1879-1889. https://doi.org/10.1039/c3nr04941h

Chen, J., Sun, L., Cheng, Y., Lu, Z., Shao, K., Li, T., Hu, C., \& Han, H. (2016). Graphene Oxide-Silver Nanocomposite: Novel Agricultural Antifungal Agent against Fusarium graminearum for Crop Disease Prevention. ACS Applied Materials and Interfaces, 8(36), 24057-24070. https://doi.org/10.1021/acsami.6b05730

Chen, M., Qin, X., \& Zeng, G. (2017). Biodegradation of Carbon Nanotubes, Graphene, and Their Derivatives. In Trends in Biotechnology, 35(9), 836-846. https://doi.org/10.1016/j.tibtech.2016.12.001

Cheng, F., Liu, Y. F., Lu, G. Y., Zhang, X. K., Xie, L. L., Yuan, C. F., \& Xu, B. B. (2016). Graphene oxide modulates root growth of Brassica napus L. and regulates ABA and IAA concentration. Journal of Plant Physiology, 193, 57-63. https://doi.org/10.1016/j.jplph.2016.02.011 
Choi, J. T., Kim, D. H., Ryu, K. S., Lee, H. Il, Jeong, H. M., Shin, C. M., Kim, J. H., \& Kim, B. K. (2011). Functionalized graphene sheet/polyurethane nanocomposites: Effect of particle size on physical properties. Macromolecular Research, 19(8), 809-814. https://doi.org/10.1007/s13233-011-0801-4

Ćirić, L., Sienkiewicz, A., Djokić, D. M., Smajda, R., Magrez, A., Kaspar, T., Nesper, R., \& Forró, L. (2010). Size dependence of the magnetic response of graphite oxide and graphene flakes - an electron spin resonance study. Physica Status Solidi (B) Basic Research, 247(11-12), 2958-2961. https://doi.org/10.1002/pssb.201000448

Combarros, R. G., Collado, S., \& Díaz, M. (2016). Toxicity of graphene oxide on growth and metabolism of Pseudomonas putida. Journal of Hazardous Materials, 310, 246-252. https://doi.org/10.1016/j.jhazmat.2016.02.038

Das, M. R., Sarma, R. K., Borah, S. C., Kumari, R., Saikia, R., Deshmukh, A. B., Shelke, M. V., Sengupta, P., Szunerits, S., \& Boukherroub, R. (2013). The synthesis of citrate-modified silver nanoparticles in an aqueous suspension of graphene oxide nanosheets and their antibacterial activity. Colloids and Surfaces B: Biointerfaces, 105, 128-136. https://doi.org/10.1016/j.colsurfb.2012.12.033

Du, S., Zhang, P., Zhang, R., Lu, Q., Liu, L., Bao, X., \& Liu, H. (2016). Reduced graphene oxide induces cytotoxicity and inhibits photosynthetic performance of the green alga Scenedesmus obliquus. Chemosphere, 164, 499-507. https://doi.org/10.1016/j.chemosphere.2016.08.138

Faria, A. F., Martinez, D. S. T., Meira, S. M. M., de Moraes, A. C. M., Brandelli, A., Filho, A. G. S., \& Alves, O. L. (2014). Anti-adhesion and antibacterial activity of silver nanoparticles supported on graphene oxide sheets. Colloids and Surfaces B: Biointerfaces, 113 , 115-124. https://doi.org/10.1016/j.colsurfb.2013.08.006

Forstner, C., Orton, T. G., Wang, P., Kopittke, P. M., \& Dennis, P. G. (2019). Effects of carbon nanotubes and derivatives of graphene oxide on soil bacterial diversity. Science of the Total Environment, 682, 356-363. https://doi.org/10.1016/j.scitotenv.2019.05.162

Geng, H., Dai, J., Li, J., Di, Z., \& Liu, X. (2016). Antibacterial ability and hemocompatibility of graphene functionalized germanium. Scientific Reports, 6(37474), 1-9. https://doi.org/10.1038/srep37474

Goodman, C. M., McCusker, C. D., Yilmaz, T., \& Rotello, V. M. (2004). Toxicity of gold nanoparticles functionalized with cationic and anionic side chains. Bioconjugate Chemistry, 15(4), 897-900. https://doi.org/10.1021/bc049951i

Gurunathan, S. (2015). Cytotoxicity of graphene oxide nanoparticles on plant growth promoting rhizobacteria. Journal of Industrial and Engineering Chemistry, 32, 282-291. https://doi.org/10.1016/j.jiec.2015.08.027

Gurunathan, S., Han, J. W., Abdal Dayem, A., Eppakayala, V., \& Kim, J. H. (2012). Oxidative stress-mediated antibacterial activity of graphene oxide and reduced graphene oxide in Pseudomonas aeruginosa. International Journal of Nanomedicine, 7, 5901-5914. https://doi.org/10.2147/IJN.S37397

Homaeigohar, S., \& Elbahri, M. (2017). Graphene membranes for water desalination. NPG Asia Materials, 9, 1-16. https://doi.org/10.1038/am.2017.135

Hou, M., Zang, X., Wang, C., \& Wang, Z. (2013). The use of silica-coated magnetic graphene microspheres as the adsorbent for the extraction of pyrethroid pesticides from orange and lettuce samples followed by GC-MS analysis. Journal of Separation Science, $36(19)$, 3242-3248. https://doi.org/10.1002/jssc.201300656

Hu, X., Kang, J., Lu, K., Zhou, R., Mu, L., \& Zhou, Q. (2014). Graphene oxide amplifies the phytotoxicity of arsenic in wheat. Scientific Reports, 4(6122), 110. https://doi.org/10.1038/srep06122

Hu, X., Lu, K., Mu, L., Kang, J., \& Zhou, Q. (2014). Interactions between graphene oxide and plant cells: Regulation of cell morphology, uptake, organelle damage, oxidative effects and metabolic disorders. Carbon, 80, 665-676. https://doi.org/10.1016/j.carbon.2014.09.010

Hu, X., \& Zhou, Q. (2013). Health and ecosystem risks of graphene. In Chemical Reviews, 113(5), 3815-3835. https://doi.org/10.1021/cr300045n

Hu, X., \& Zhou, Q. (2014). Novel hydrated graphene ribbon unexpectedly promotes aged seed germination and root differentiation. Scientific Reports, 10(1038), 1-9. https://doi.org/10.1038/srep03782

Hui, L., Piao, J. G., Auletta, J., Hu, K., Zhu, Y., Meyer, T., Liu, H., \& Yang, L. (2014). Availability of the basal planes of graphene oxide determines whether it is antibacterial. ACS Applied Materials and Interfaces, 6(15), 13183-13190. https://doi.org/10.1021/am503070z

Hummers, W. S., \& Offeman, R. E. (1958). Preparation of Graphitic Oxide. Journal of the American Chemical Society, 80(6), 1339. https://doi.org/10.1021/ja01539a017

Jain, R., \& Mishra, S. (2016). Electrical and electrochemical properties of graphene modulated through surface functionalization. RSC Advances, 6(33), 2740427415. https://doi.org/10.1039/c5ra26533a

Kabiri, S., Degryse, F., Tran, D. N. H., Da Silva, R. C., McLaughlin, M. J., \& Losic, D. (2017). Graphene Oxide: A New Carrier for Slow Release of Plant Micronutrients. ACS Applied Materials and Interfaces, 9(49), 43325-43335. https://doi.org/10.1021/acsami.7b07890

Kim, M. J., Kim, W., \& Chung, H. (2020). Effects of silver-graphene oxide on seed germination and early growth of crop species. PeerJ., 2020(1), 1-14. https://doi.org/10.7717/peerj.8387

Kurapati, R., Russier, J., Squillaci, M. A., Treossi, E., Ménard-Moyon, C., Del Rio-Castillo, A. E., Vazquez, E., Samorì, P., Palermo, V., \& Bianco, A. (2015). Dispersibility-Dependent Biodegradation of Graphene Oxide by Myeloperoxidase. Small, 11(32), 3985-3994. https://doi.org/10.1002/smll.201500038

Lee, D. Y., Khatun, Z., Lee, J. H., Lee, Y. K., \& In, I. (2011). Blood compatible graphene/heparin conjugate through noncovalent chemistry. Biomacromolecules, 12(2), 336-341. https://doi.org/10.1021/bm101031a

Lehner, B. A. E., Janssen, V. A. E. C., Spiesz, E. M., Benz, D., Brouns, S. J. J., Meyer, A. S., \& van der Zant, H. S. J. (2019). Creation of Conductive Graphene Materials by Bacterial Reduction Using Shewanella Oneidensis. ChemistryOpen, 8(7), 888-895. https://doi.org/10.1002/open.201900186 
Liang, Y., Yang, D., \& Cui, J. (2017). A graphene oxide/silver nanoparticle composite as a novel agricultural antibacterial agent against Xanthomonas oryzae pv. oryzae for crop disease management. New Journal of Chemistry, 41, 13692-13699. https://doi.org/10.1039/c7nj02942j

Liu, Shangjie, Wei, H., Li, Z., Li, S., Yan, H., He, Y., \& Tian, Z. (2015). Effects of graphene on germination and seedling morphology in rice. Journal of Nanoscience and Nanotechnology, 15(4), 2695-2701. https://doi.org/10.1166/jnn.2015.9254

Liu, Shaobin, Hu, M., Zeng, T. H., Wu, R., Jiang, R., Wei, J., Wang, L., Kong, J., \& Chen, Y. (2012). Lateral dimension-dependent antibacterial activity of graphene oxide sheets. Langmuir, 28(33), 12364-12372. https://doi.org/10.1021/la3023908

Liu, Shaobin, Zeng, T. H., Hofmann, M., Burcombe, E., Wei, J., Jiang, R., Kong, J., \& Chen, Y. (2011). Antibacterial activity of graphite, graphite oxide, graphene oxide, and reduced graphene oxide: Membrane and oxidative stress. ACS Nano, 5(9), 6971-6980. https://doi.org/10.1021/nn202451x

Lu, T., Xia, T., Qi, Y., Zhang, C., \& Chen, W. (2017). Effects of clay minerals on transport of graphene oxide in saturated porous media. Environmental Toxicology and Chemistry, 36(3), 655-660. https://doi.org/10.1002/etc.3605

Luo, J., Cote, L. J., Tung, V. C., Tan, A. T. L., Goins, P. E., Wu, J., \& Huang, J. (2010). Graphene oxide nanocolloids. Journal of the American Chemical Society, 50, 17667-17669. https://doi.org/10.1021/ja1078943

Ma, L., Zhu, Z., Su, M., Ma, L., Liu, D., \& Wang, Z. (2013). Preparation of graphene oxide-silver nanoparticle nanohybrids with highly antibacterial capability. Talanta, 117, 449-455. https://doi.org/10.1016/j.talanta.2013.09.017

Mangadlao, J. D., Santos, C. M., Felipe, M. J. L., De Leon, A. C. C., Rodrigues, D. F., \& Advincula, R. C. (2015). On the antibacterial mechanism of graphene oxide (GO) Langmuir-Blodgett films. Chemical Communications, 51, 2886-2889. https://doi.org/10.1039/c4cc07836e

Mejías Carpio, I. E., Santos, C. M., Wei, X., \& Rodrigues, D. F. (2012). Toxicity of a polymer-graphene oxide composite against bacterial planktonic cells, biofilms, and mammalian cells. Nanoscale, 12, 4746-4756. https://doi.org/10.1039/c2nr30774j

Möhler, J. S., Sim, W., Blaskovich, M. A. T., Cooper, M. A., \& Ziora, Z. M. (2018). Silver bullets: A new lustre on an old antimicrobial agent. In Biotechnology Advances, 36(5), 1391-1411. https://doi.org/10.1016/j.biotechadv.2018.05.004

Nair, R., Mohamed, M. S., Gao, W., Maekawa, T., Yoshida, Y., Ajayan, P. M., \& Kumar, D. S. (2012). Effect of carbon nanomaterials on the germination and growth of rice plants. Journal of Nanoscience and Nanotechnology, 12(3), 2212-2220. https://doi.org/10.1166/jnn.2012.5775

Nika, D. L., Askerov, A. S., \& Balandin, A. A. (2012). Anomalous size dependence of the thermal conductivity of graphene ribbons. Nano Letters, 12(6), 32383244. https://doi.org/10.1021/n1301230g

Novoselov, K. S., Jiang, D., Schedin, F., Booth, T. J., Khotkevich, V. V., Morozov, S. V., \& Geim, A. K. (2005). Two-dimensional atomic crystals. Proceedings of the National Academy of Sciences of the United States of America, 102(30), 10451-10453. https://doi.org/10.1073/pnas.0502848102

Ocsoy, I., Paret, M. L., Ocsoy, M. A., Kunwar, S., Chen, T., You, M., \& Tan, W. (2013). Nanotechnology in plant disease management: DNA-directed silver nanoparticles on graphene oxide as an antibacterial against Xanthomonas perforans. ACS Nano, 7(10), 8972-8980. https://doi.org/10.1021/nn4034794

Park, S., Choi, K. S., Kim, S., Gwon, Y., \& Kim, J. (2020). Graphene Oxide-Assisted Promotion of Plant Growth and Stability. 10(758), 1-11. https://doi.org/10.3390/nano10040758

Perreault, F., Faria, A. F., Nejati, S., \& Elimelech, M. (2015). Antimicrobial Properties of Graphene Oxide Nanosheets: Why Size Matters. ACS Nano, 9(7), 7226-7236. https://doi.org/10.1021/acsnano.5b02067

Prasad, K., Lekshmi, G. S., Ostrikov, K., Lussini, V., Blinco, J., Mohandas, M., Vasilev, K., Bottle, S., Bazaka, K., \& Ostrikov, K. (2017). Synergic bactericidal effects of reduced graphene oxide and silver nanoparticles against Gram-positive and Gram-negative bacteria. Scientific Reports, 7(1591), 1-11. https://doi.org/10.1038/s41598-017-01669-5

Ren, W., Chang, H., \& Teng, Y. (2016). Sulfonated graphene-induced hormesis is mediated through oxidative stress in the roots of maize seedlings. Science of the Total Environment, 1(572), 926-934. https://doi.org/10.1016/j.scitotenv.2016.07.214

Ren, W., Ren, G., Teng, Y., Li, Z., \& Li, L. (2015). Time-dependent effect of graphene on the structure, abundance, and function of the soil bacterial community. Journal of Hazardous Materials, 297, 286-294. https://doi.org/10.1016/j.jhazmat.2015.05.017

Sawangphruk, M., Srimuk, P., Chiochan, P., Sangsri, T., \& Siwayaprahm, P. (2012). Synthesis and antifungal activity of reduced graphene oxide nanosheets. Carbon, 50(14), 5156-5161. https://doi.org/10.1016/j.carbon.2012.06.056

Seo, J. W. T., Green, A. A., Antaris, A. L., \& Hersam, M. C. (2011). High-concentration aqueous dispersions of graphene using nonionic, biocompatible block copolymers. Journal of Physical Chemistry Letters, 2(9), 1004-1008. https://doi.org/10.1021/jz2003556

Shao, W., Liu, X., Min, H., Dong, G., Feng, Q., \& Zuo, S. (2015). Preparation, characterization, and antibacterial activity of silver nanoparticle-decorated graphene oxide nanocomposite. ACS Applied Materials and Interfaces, 7(12), 6966-6973. https://doi.org/10.1021/acsami.5b00937

Shen, S., Liu, Y., Wang, F., Yao, G., Xie, L., \& Xu, B. (2019). Graphene Oxide Regulates Root Development and Influences IAA Concentration in Rice. Journal of Plant Growth Regulation, 38, 241-248. https://doi.org/10.1007/s00344-018-9836-5

Soldano, C., Mahmood, A., \& Dujardin, E. (2010). Production, properties and potential of graphene. In Carbon, 48, 2127-2150. https://doi.org/10.1016/j.carbon.2010.01.058

Somanathan, T., Prasad, K., Ostrikov, K. K., Saravanan, A., \& Krishna, V. M. (2015). Graphene oxide synthesis from agro waste. Nanomaterials, 5(2), 826834. https://doi.org/10.3390/nano5020826 
Song, B., Tang, J., Zhen, M., \& Liu, X. (2019). Influence of graphene oxide and biochar on anaerobic degradation of petroleum hydrocarbons. Journal of Bioscience and Bioengineering, 128(1), 72-79. https://doi.org/10.1016/j.jbiosc.2019.01.006

Song, J., Duan, C., Sang, Y., Wu, S., Ru, J., \& Cui, X. (2018). Effects of graphene on bacterial community diversity and soil environments of Haplic Cambisols in Northeast China. Forests, 9(677) 1-18. https://doi.org/10.3390/f9110677

Sundramoorthy, A. K., Vignesh Kumar, T. H., \& Gunasekaran, S. (2018). Graphene-Based Nanosensors and Smart Food Packaging Systems for Food Safety and Quality Monitoring. In Graphene Bioelectronics, 2018, 267-306. https://doi.org/10.1016/B978-0-12-813349-1.00012-3

Surwade, S. P., Smirnov, S. N., Vlassiouk, I. V., Unocic, R. R., Veith, G. M., Dai, S., \& Mahurin, S. M. (2015). Water desalination using nanoporous singlelayer graphene. Nature Nanotechnology, 10(5), 459-464. https://doi.org/10.1038/nnano.2015.37

Tang, J., Chen, Q., Xu, L., Zhang, S., Feng, L., Cheng, L., Xu, H., Liu, Z., \& Peng, R. (2013). Graphene oxide-silver nanocomposite as a highly effective antibacterial agent with species-specific mechanisms. ACS Applied Materials and Interfaces, 5(9), 3867-3874. https://doi.org/10.1021/am4005495

Wang, D., Wang, G., Zhang, G., Xu, X., \& Yang, F. (2013). Using graphene oxide to enhance the activity of anammox bacteria for nitrogen removal. Bioresource Technology, 131, 527-530. https://doi.org/10.1016/j.biortech.2013.01.099

Wang, X., Han, H., Liu, X., Gu, X., Chen, K., \& Lu, D. (2012). Multi-walled carbon nanotubes can enhance root elongation of wheat (Triticum aestivum) plants. Journal of Nanoparticle Research, 6, 1-10. https://doi.org/10.1007/s11051-012-0841-5

Wang, X., Liu, X., Chen, J., Han, H., \& Yuan, Z. (2014). Evaluation and mechanism of antifungal effects of carbon nanomaterials in controlling plant fungal pathogen. Carbon, 68, 798-806. https://doi.org/10.1016/j.carbon.2013.11.072

Wiche, O., Székely, B., Moschner, C., \& Heilmeier, H. (2018). Germanium in the soil-plant system-a review. In Environmental Science and Pollution Research, 25, 31938-31956. https://doi.org/10.1007/s11356-018-3172-y

Wu, L., Fu, X., Liu, H., Li, J., \& Song, Y. (2014). Comparative study of graphene nanosheet- and multiwall carbon nanotube-based electrochemical sensor for the sensitive detection of cadmium. Analytica Chimica Acta, 851, 843-848. https://doi.org/10.1016/j.aca.2014.08.021

Wu, Q., Feng, C., Zhao, G., Wang, C., \& Wang, Z. (2012). Graphene-coated fiber for solid-phase microextraction of triazine herbicides in water samples. Journal of Separation Science, 35(2), 193-199. https://doi.org/10.1002/jssc.201100740

You, Y., Jin, X. H., Wen, X. Y., Sahajwalla, V., Chen, V., Bustamante, H., \& Joshi, R. K. (2018). Application of graphene oxide membranes for removal of natural organic matter from water. Carbon, 129(1), 415-419. https://doi.org/10.1016/j.carbon.2017.12.032

Zaytseva, O., \& Neumann, G. (2016). Carbon nanomaterials: Production, impact on plant development, agricultural and environmental applications. Chemical and Biological Technologies in Agriculture, 3(1), 1-26. https://doi.org/10.1186/s40538-016-0070-8

Zhang, M., Gao, B., Chen, J., \& Li, Y. (2015). Effects of graphene on seed germination and seedling growth. Journal of Nanoparticle Research, 8(8387), 1-14. https://doi.org/10.1007/s11051-015-2885-9

Zhang, M., Gao, B., Chen, J., Li, Y., Creamer, A. E., \& Chen, H. (2014). Slow-release fertilizer encapsulated by graphene oxide films. Chemical Engineering Journal, 255(1), 107-113. https://doi.org/10.1016/j.cej.2014.06.023

Zhao, J., Wang, Z., White, J. C., \& Xing, B. (2014). Graphene in the aquatic environment: Adsorption, dispersion, toxicity and transformation. Environmental Science and Technology, 48(17), 9995-10009. https://doi.org/10.1021/es5022679

Zhou, K., Zhu, Y., Yang, X., Jiang, X., \& Li, C. (2011). Preparation of graphene-TiO2 composites with enhanced photocatalytic activity. New Journal of Chemistry, 35(2), 353-359. https://doi.org/10.1039/c0nj00623h

Zhu, Y., Murali, S., Cai, W., Li, X., Suk, J. W., Potts, J. R., \& Ruoff, R. S. (2010). Graphene and graphene oxide: Synthesis, properties, and applications. Advanced Materials, 22, 3906-3924. https://doi.org/10.1002/adma.201001068 